\title{
NILAI-NILAI ISLAM DALAM KONSTRUKSI SOSIAL KONSERVASI LINGKUNGAN PESISIR (STUDI DI MANGROVE CENTER TUBAN)
}

\author{
Fandi Sudiasmo \\ Jurusan Sosiologi \\ Universitas Islam Balitar \\ fandisudiasmo@gmail.com
}

\begin{abstract}
Various problems related to the growth of coastel area are rapidly relative, definitely the handling steps immediately should be concepted. In addition of what have been predicted, in this time one demage of the coastel area is demaged of mangrove, so that why the conservation in coastel area extremely needed because there are several benefits for society. Mangrove Center of Tuban (MCT) is one of institute that has been developing the conservation of coastel area. The purpose in this research is understanding the values of Islam in social construction of coastel area conservation in Tuban Mangroves Center, utilised the qualitative research with phenomenological approach, use the analysis techniques of research phenomenological Creswell data, did in Jenu village- Jenu subdistricts regency of Tuban. The existency of conservation activities surely not released to the process of social construction. The concept of social construction is the meaning of each individul process for each areas and each outside aspect consist of Externalitation process, Objectivation, and internalitation. Start from the activities, planting of mangrove that planted everyday, be a habits, have an institute other socialitation to make some conservations. Conservation activities as a realization of values in religion (Islam), pay attention to some areas not liberated from the verses of the holy Qur'an (QS Al Isra (17): 44).
\end{abstract}

Keywords: social construction, concervation, and Islam

\section{PENDAHULUAN}

Berbagai masalah berkaitan dengan pertumbuhan daerah pesisir relatif pesat, seperti yang telah diyakini oleh para ahli adalah adanya ancaman global warming yang dapat menyebabkan banyak bencana, seperti banjir, angin topan, musim kemarau panjang, evaporasi air tawar, meluasnya kebakaran hutan, dan bencana-bencana lain. Hal paling nyata ancaman global warming adalah semakin naiknya permukaan air laut. Kelompok yang nyata akan menjadi korban pertama global warming adalah negara-negara yang memiliki lokasi kelautan, dalam hal ini masyarakat pesisirlah yang paling terancam. Indonesia sendiri adalah negara kelautan yang dihuni oleh banyak populasi pesisirnya, tentu langkah-langkah penanganan harus segera digagas.

Saat ini salah satu kerusakan lingkungan pesisir adalah rusaknya hutan mangrove, selain dari apa yang sudah diramalkan. Keadaan hutan mangrove di Indonesia dapat dikatakan sudah rusak berat. Luas hutan mangrove sebelum tahun 1980 sekitar 20 juta hektar, dan pada tahun 1994 diperkirakan tinggal 4,25 juta hektar 
(Adisasmita, 2006:55). Melihat dari berbagai masalah dan hasil penelitian di atas yang pastinya berdampak terhadap masyarakat, maka jelas bahwa proses konservasi lingkungan pesisir sangatlah diperlukan, sehingga didapat sebuah sosuli untuk mengatasi isu-isu strategis seperti terpapar di atas.

Konservasi wilayah pesisir sangatlah dibutuhkan mengingat beberapa manfaat yang dihasilkannya, antara lain ialah manfaat biogeografi, keanekaragaman hayati, perlindungan terhadap spesies endemik dan spesies langka, perlindungan terhadap spesies yang rentan dalam masa pertumbuhan, pengurangan mortalitas, perlindungan pemijahan, manfaat penelitian, ekoturism, dan peningkatan produktivitas perairan (Fauzi dan Anna, dalam Amelia, 2013). Manfaat konservasi tersebut, mencakup manfaat langsung maupun tidak langsung. Manfaat konservasi wilayah pesisir tidak hanya bersifat terukur (tangible), tetapi ada juga yang tidak terukur (intangible). Manfaat yang terukur mencakup manfaat kegunaan baik untuk dikonsumsi maupun tidak, sedangkan manfaat tidak terukur lebih tertuju pada manfaat pemeliharaan ekosistem dalam jangka panjang.

Sebagai tempat bertemunya daratan dan lautan, pesisir memang memiliki berbagai masalah dan banyak hal menarik di dalamnya, untuk itu peran dari gerakan lingkungan sangatlah dibutuhkan. Ada beberapa kelompok aliran gerakan lingkungan di dunia. Menurut Tom Dietz (dalam Parlan, 2002:42) gerakan lingkungan dikelompokkan menjadi tiga, pertama ecofascism, yaitu kelompok yang memperjuangkan masalah lingkungan demi lingkungan sendiri. Kedua adalah eco-developmentalism yaitu gerakan lingkungan yang dilakukan bukan hanya memperjuangkan lingkungan, tetapi berjuang demi keberlangsungan pertumbuhan ekonomi, sedangkan yang ketiga adalah eco-populism, adalah gerakan lingkungan yang memihak kepada kepentingan rakyat banyak demi kesejahteraan sosial.

Paham-paham tersebut baik secara sadar maupun tidak telah banyak dianut oleh aktivis lingkungan di Indonesia, baik secara periodik maupun bersama-sama dalam satu waktu. Hal ini dapat kita lihat dari pola-pola gerakan lingkungan yang terjadi di Indonesia. Misalnya Mangrove Center Tuban (MCT), yang merupakan pusat pendidikan lingkungan hidup pesisir dan laut di Kabupaten Tuban Jawa Timur. MCT mulai dikembangkan sejak tahun 1997 oleh Kelompok Tani di Desa Jenu, Kecamatan Jenu Kabupaten Tuban yang kemudian ternaungi dalam wadah Forum Komunikasi Peduli Lingkungan Pesisir Tuban. MCT bertempat di Pantai Utara Kabupaten Tuban dengan alamat Jl.Raya Tuban-Semarang KM 9 Desa Jenu, Kecamatan Jenu Kabupaten Tuban Jawa Timur.

Kawasan hijau yang berdiri di atas lahan seluas 56 hektar ini (MCT) tidak serta-merta berubah menjadi sebuah area yang sejuk dipandang seperti sekarang ini. MCT menjadi seperti yang saat ini berawal dari kesadaran seorang H. Ali yang terinspirasi dari Ayat-ayat dalam Al-Quran dan dikembangkan dengan memberikan penyadaran pula kepada yang lain guna menjaga kelestarian lingkungan pesisir melalui mangrove sebagai bentuk konservasi lingkungan. Adanya kegiatan konservasi tersebut tentu tak lepas dari suatu proses konstruksi sosial.

Konstruksi sosial berasal dari filsafat Kontruktivisme yang dimulai dari gagasangagasan konstruktif kognitif, menurut Von Glasersfeld pengertian konstruktif kognitif muncul dalam tulisan Mark Baldwin yang secara luas diperdalam dan disebarkan oleh Jean Piaget. Namun apabila ditelusuri, sebenarnya gagasangagasan pokok Konstruktivisme sebenarnya telah dimulai oleh Giambatissta Vico, seorang epistemologi dari Italia, ia adalah cikal bakal Konstruktivisme (Suparno dalam Amelia, 2013).

Kontruksi sosial memiliki arti yang luas dalam ilmu sosial, yang biasanya dihubungkan pada pengaruh sosial dalam pengalaman hidup individu. Berasumsi dasar pada "realitas adalah kontruksi sosial" dari Berger dan Luckmann, menurutnya kontruksi sosial memiliki beberapa

Fandi Sudiasmo, Nilai-nilai Islam dalam Konstruksi Sosial Konservasi Lingkungan Pesisir (Studi di Mangrove Center Tuban) 
kekuatan. Pertama, peran sentral bahasa memberikan mekanisme konkret, di mana budaya mempengaruhi pikiran dan tingkah laku individu. Kedua, kontruksi sosial dapat mewakili kompleksitas dalam satu budaya tunggal, hal ini tidak mengasumsikan keseragaman. Ketiga, hal ini bersifat konsisten dengan masyarakat dan waktu. Kontruksi sosial merupakan sebuah pandangan kepada kita bahwa semua nilai, ideologi, dan institusi sosial adalah buatan manusia.

Kontruksi sosial adalah sebuah pernyataan keyakinan (a claim) dan juga sebuah sudut pandang (a viewpoint) bahwa kandungan dari kesadaran, dan cara berhubungan dengan orang lain itu diajarkan oleh kebudayaan dan masyarakat. Tercakup di dalamnya pandangan bahwa semua kuantitas metafisik riil dan abstrak yang dianggap sebagai suatu kepastian itu dipelajari dari orang lain di sekitar kita (Rory dalam Berger \& Luckman, 2012:4).

Konsep dari konstruksi sosial tersebut adalah suatu proses pemaknaan yang dilakukan oleh setiap individu terhadap lingkungan dan aspek di luar dirinya yang terdiri dari proses eksternalisasi, objektivasi, internalisasi, dan eksternalisasi adalah penyesuaian diri dengan dunia sosiokultural sebagai produk manusia. Objektivasi adalah interaksi sosial dalam dunia intersubjektif yang dilembagakan atau mengalami proses institusionalisasi. Internalisasi adalah individu mengidentifikasi diri di tengah lembaga-lembaga sosial di mana individu tersebut menjadi anggotanya. Penelitian ini dilakukan dengan tujuan untuk mengetahui konstruksi sosial konservasi lingkungan pesisir di Mangrove Center Tuban (MCT) yang digagas oleh seseorang yang terinspiarasi dari Ayat-ayat dalam Al-Quran.

\section{METODE}

Penelitian ini menggunakan jenis penelitian kualitatif dengan memakai pendekatan fenomenologi, guna dapat mendeskripsikan kejadian dan kenyataan yang sebenar-benarnya tentang hal yang diteliti. Penelitian dilakukan di Desa Jenu Kecamatan Jenu Kabupaten Tuban, terkhusus yang menjadi kawasan konservasi dari Mangrove Center Tuban (MCT), dengan alasan karena lokasi tersebut karena terdapat sebuah yayasan pusat pendidikan lingkungan yang bernama Mangrove Center yang bergerak di bidang konservasi lingkungan pesisir. Penelitian dilakukan pada tahun 2014-2015.

Teknik sampling purposive yang dipakai dalam penelitian ini dengan sampel pertamanya adalah H. Ali Mansur selaku pembina tetap dari Mangrove Center Tuban (MCT), selanjutnya adalah Zainal Abidin ketua kelompok tani. Sumber data diperoleh secara langsung dari subjek yang diteliti, dengan cara mengadakan wawancara secara langsung dan observasi langsung di lokasi penelitian dan sumber data yang diperoleh dari arsip, internet tentang situssitus yang terkait dengan konteks penelitian dan juga buku yang sekiranya menunjang. Melalui observasi, peneliti belajar tentang perilaku, dan makna dari perilaku tersebut, wawancara, serta dokumentasi berupa foto-foto dari lokasi penelitian, berkas-berkas yang bisa menunjang data dalam penelitian ini, kemudian data tersebut dikaji kembali dengan maksud untuk melengkapi data-data yang diperoleh sebelumnya.

Teknik analisis data menggunakan teknik analisa data penelitian fenomenologi yang disajikan oleh Creswell (dalam Novianti, 2013), dalam bentuk tabel seperti di bawah ini. 


\begin{tabular}{|c|c|}
\hline 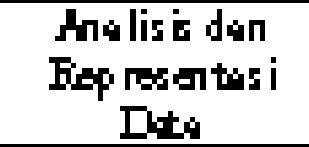 & $\begin{array}{c}\text { Fa elitis n } \\
\text { Fonomeno be }\end{array}$ \\
\hline Fryphlyinth & 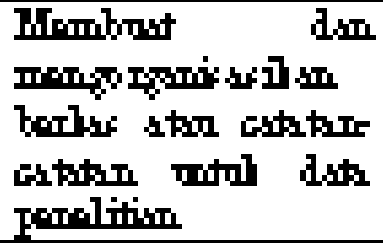 \\
\hline 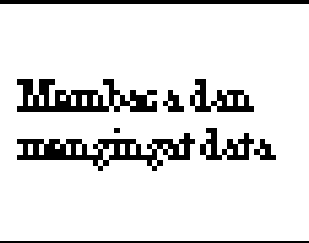 & 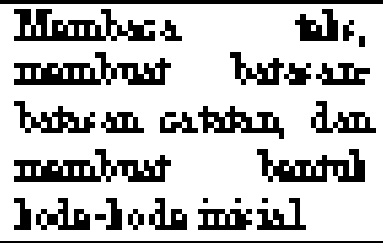 \\
\hline 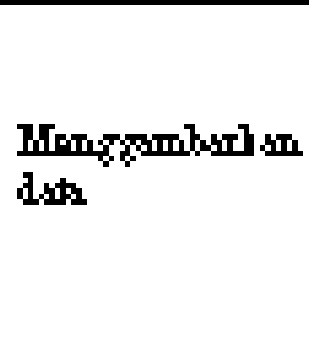 & 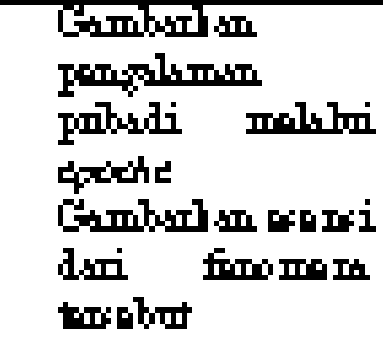 \\
\hline Flatiflatht & 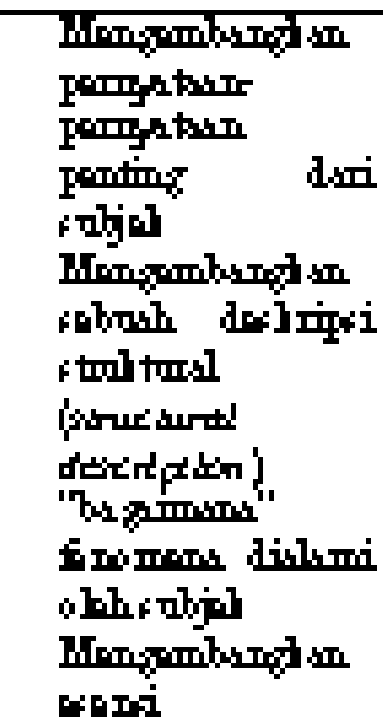 \\
\hline 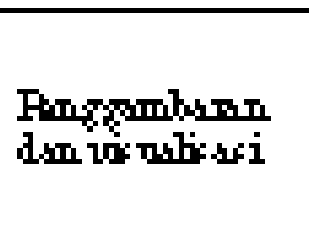 & 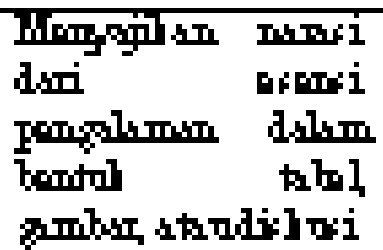 \\
\hline
\end{tabular}

\section{HASIL DAN PEMBAHASAN}

\section{Konstruksi Sosial Konservasi Lingkungan di Mangrove Center Tuban}

Mangrove Center Tuban (MCT) merupakan pusat pendidikan lingkungan hidup pesisir dan laut di Kabupaten Tuban Jawa Timur. MCT mulai dikembangkan sejak tahun 1997 oleh Kelompok Tani di Desa Jenu, Kecamatan Jenu Kabupaten Tuban yang kemudian ternaungi dalam wadah Forum Komunikasi Peduli Lingkungan Pesisir Tuban. MCT bertempat di Pantai Utara Kabupaten Tuban dengan alamat Jl. Raya Tuban-Semarang KM 9 Desa Jenu, Kecamatan Jenu Kabupaten Tuban Jawa Timur. Visi; Terciptanya kelestarian lingkungan pesisir pantai Tuban yang bersih, indah, dan asri guna mewujudkan kesejahteraan masyarakat, dan Misi; (1) mensosialisasikan dan membudidayakan tanaman pantai terutama mangrove di pantai Tuban; (2) memanfaatkan secara bijaksana dan terpadu pada tanaman pantai Tuban; (3) menciptakan hutan pantai yang bersih, indah dan asri guna mewujudkan wisata pantai; (4) meningkatkan kesejahteraan masyarakat melalui unit usaha koperasi; (5) membangun kemitraan serta memperluas jaringan dengan lembaga dan instansi lain.

Mangrove Center Tuban (MCT) melakukan beberapa program non-profit dengan garis besar meliputi (1) pendidikan lingkungan hidup pesisir, (2) pembibitan dan penghijauan kawasan pesisir Tuban dan setiap wilayah yang membutuhkan peran MCT, (3) penyediaan fasilitas untuk siswa, mahasiswa maupun umum yang akan melakukan penelitian seputar lingkungan hidup dengan menyediakan perpustakaan, green house dan laboratorium alam. Fasilitas yang disediakan di Mangrove Center Tuban (MCT) antara lain (1) taman baca, (2) green house, (3) laboratorium alam, (4) balai workshop, (5) balai pertemuan, (6) lokasi pembibitan, (7) camping ground, dan (8) Pondokan. 


\section{HASIL}

\section{Proses Eksternalisasi di Mangrove Center Tuban (MCT)}

MCT yang kini luasnya mencapai sekitar 56 hektar itu tidak serta-merta berubah menjadi sebuah area yang indah seperti sekarang ini. Dulunya kawasan ini adalah pesisir pantai yang banyak ditumbuhi pohon kelapa. Sayangnya, di tahun 1979-an terjadilah wabah besar yang menyerang pohon-pohon kelapa tersebut, di mana semua pohon-pohon kelapa terserang oleh wabah kwawung secara besar-besaran sampai tak satupun pohon kelapa tersebut tersisa. Setahun setelahnya, tepatnya di tahun 1980-an pesisir pantai Jenu terkena libasan ombak yang begitu dahsyat, hingga terjadilah kerusakan tanah yang luar biasa. Daya terjang ombak sampai ke daratan dan merusak infrastruktur di pinggir-pinggir jalan raya.

Prihatin dengan semakin memburuknya keadaan itu menggerakkan nurani seorang $\mathrm{H}$. Ali Mansyur sebagai warga asli Desa Jenu untuk melakukan rehabilitasi terhadap kerusakan saat itu. Berawal dari 1,2 hektar tanah di tepi pantai yang ia miliki, H. Ali berusaha mencurahkan diri dengan menanami kembali tanahnya dengan beberapa pohon mangrove. H. Ali melihat bahwa dulu awalnya pantai tersebut adalah sebuah pantai yang bagus, akibat tangan manusia yang tidak arif kepada lingkungan telah mengakibatkan pantai tersebut mengalami kerusakan. Salah satu faktor penyebab kerusakan pantai antara lain adalah karena adanya penambangan pasir untuk dijual oleh masyarakat. Melihat kondisi pantai yang telah mengalami kerusakan waktu itu, dari situlah ada keinginan untuk mengembalikan fungsi pantai dengan cara menanami mangrove. Awalnya H. Ali hanya berkeinginan untuk menyelamatkan tanahnya sendiri yang terkena abrasi, waktu itu bibit diambilnya dari Ujung Pangkah Kulon Gresik dan dari Brondong Lamongan.

Lahan 1,2 itu mulai beliau garap sendiri, beliau tanami pohon sendiri dengan bibit yang beliau cari-cari sendiri. Waktu terus berjalan, pohon yang dia tanam mulai tumbuh dan subur. Tak hanya mangrove, lebih dari itu telah berkembang ke pohon keras seperti pohon cemara udang dengan berbagai varitasnya. Bahkan $\mathrm{H}$. Ali sampai-sampai kekurangan lahan. Maka, dibelilah lahan samping kanan-kiri untuk terus melakukan perluasan terhadap niatnya dalam menghijaukan pantai Jenu. Waktu itu tanah dibeli dengan perhektar seharga 4 juta atau 400 rupiah permeternya.

Tahun 1997 hamparan pantai berpasir yang rusak berat itu telah berubah drastis menjadi sebuah hutan mini yang hijau nan indah. Kemudian di tahun 1998 saat krisis monter berlangsung hutan mangrove binaan $\mathrm{H}$. Ali akhirnya mendapatkan bantuan dari pemerintah berupa 50.000 bibit seharga 3.300 perbatang. Di tahun 2000 muncul para petani-petani baru yang juga ikut mengembangkan mangrove. Kurang lebih ada 12 kelompok tani. Kemudian dibentuklah sebuah komunitas baru yaitu sebuah komunitas yang sadar dan peduli akan lingkungan. Komunitas ini selanjutnya diberi nama "Forum Lingkungan Peduli Pesisir Pantai".

Hutan magrove saat itu tak hanya sebagai pusat tanaman mangrove dan tanaman-tanaman pesisir pantai. Hutan mangrove telah menjelma menjadi sebuah laboratorium alam pantai utara, objek wisata yang mendidik, tempat latihan kepemimpinan dan area perkemahan nasional. Para aktivis pendidikan yang memanfaatkan area ini banyak belajar tentang bagaimana proses pembibitan, penanaman, dan tentang konservasi lingkungan. Selanjutnya, di tahun 2005 hutan mangrove diresmikan menjadi "Mangrove Center Tuban (MCT)", dan semenjak saat itu MCT telah resmi menjadi Pusat Pendidikan Lingkungan Hidup (PPLH) yang bersih dari singgungan parpol dan ormas tertentu. MCT sendiri saat ini mempunyai 52 tim pengelola yang sadar dan peduli terhadap lingkungan. Dari 52 orang tersebut dibagi menjadi 14 bidang. Masingmasing bidang terdiri dari 4 orang. 
Banyaknya dorongan untuk melakukan pembibitan tanaman keras membuat $\mathrm{H}$. Ali Mansyur mulai berpikir bagaimana kalau mangrove Center memang tidak hanya sebagai bank benih mangrove dan cemara saja. Maka, mulailah dilakukan pembibitan pohon-pohon keras seperti mahoni, jati, trembesi, matoa, sengon, rambutan, dan duren. Sampai kini nyaris tiap hari tak pernah sepi pembeli. Pesanan pun terus mengalir tiada henti. Ada yang dari Pasuruan, Malang, Madiun, Ponorogo, Pacitan, Madura, Rembang, Gresik dan lain-lain. Pembibitan tidak cuma untuk pesisir, tetapi juga disemua yang membutuhkan penghijauan.

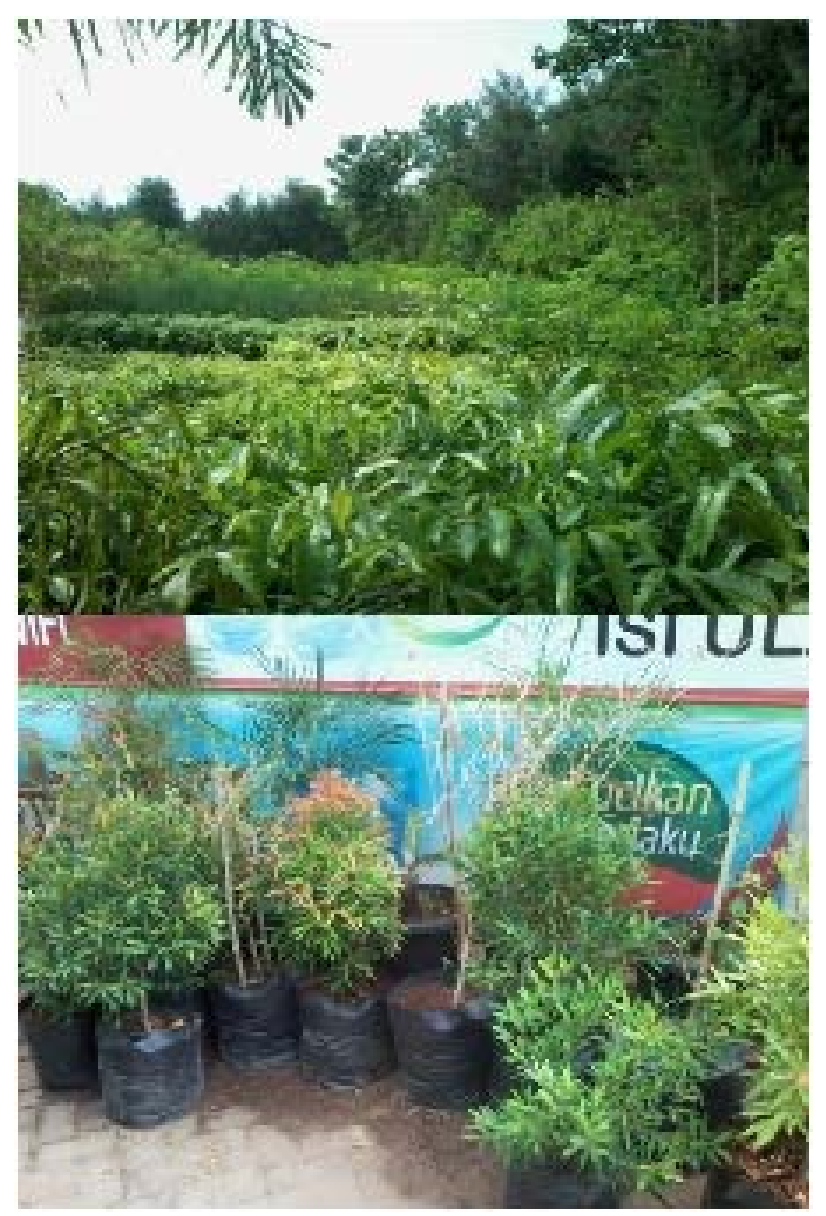

Gambar 1. Bibit Mangrove di MCT

Bagi H. Ali hal ini tidak lepas dari ajaran agama dan keyakinannya, apa yang dilakukannya adalah sebagai "ibadah, sedekah lewat bibit", begitu beliau menyatakan. Siapa pun yang membutuhkan penghijauan akan diberi, cuma dengan mengganti biaya transportasi saja kalau lokasi pengiriman jauh, dan kalau pabrik yang membutuhkan diberi harga, dikenakan biaya perawatan dan polibek. Untuk memenuhi permintaan bibit yang terus meningkat tentunya membutuhkan modal yang tidak sedikit. $\mathrm{H}$. Ali Mansyur punya trik tersendiri, dia melakukan subsidi silang dengan hasil tambak dan peternakan miliknya yang tersebar di seluruh wilayah Tuban. Selama pemenuhan kebutuhan bibit bisa dilakukan secara mandiri, pantang bagi seorang H. Ali Mansyur untuk meminta. Barulah kalau permohonan bibit itu dalam skala sangat besar dia akan menggandeng perusahaan-perusahaan swasta untuk mencairkan CSR-nya.

Kian hari permintaan bibit kian banyak, apalagi sekarang ini luas MCT mencapai 56 hektar. Untuk mensiasati hal itu H. Ali melakukan subsidi silang dengan hasil tambak dan beberapa ternak pribadi yang tersebar di seluruh wilayah Tuban. "Alhamdulillah sampai detik ini soal keuangan kami tidak pernah kekurangan" kata H. Ali. Kalau ada permintaan bibit dalam skala besar, MCT baru menggandeng instansi pemerintah atau perusahaan swasta setempat. Kenapa dipilih cemara laut ditanam sebagai garda depan yang lebih dekat dengan air? Belajar pada pengalaman tahun 2008 , kedahsyatan ombak di laut Jawa yang berlangsung selama sebulan lebih telah menghempaskan 105 hektar lahan mangrove di pesisir pantai Tuban. Hampir sepanjang pantai waktu itu lahan konservasi mangrove rusak berat dan terbawa arus air laut, sementara pohon cemara laut tetap kokoh berdiri dan hanya sedikit sekali yang mengalami kerusakan. Maka mengambil pelajaran dari semua peristiwa itu MCT secara besar-besaran membudidayakan cemara laut sebagai tanaman yang berfungsi menangkal abrasi pantai.

"Dulu berjuang sendiri, sekarang tidak. adipura harga mati di Tuban", begitu menurut H. Ali, beliau juga mengatakan bahwa saat ini pemerintah sadar akan bagaimana pentingnya menjaga lingkungan. Sekitar tahun 20112012 Pak Karwo (sapaan akrab Gubernur

Fandi Sudiasmo, Nilai-nilai Islam dalam Konstruksi Sosial Konservasi Lingkungan Pesisir (Studi di Mangrove Center Tuban) 
Jatim) meresmikan Bank Benih Mangrove dan Mangrove Center Tuban (MCT). Ia menjelaskan, Pemerintah ingin membantu untuk menanami pantai Desa Jenu Kabupaten Tuban dengan mangrove dan cemara laut untuk menahan abrasi dan mengatasi pemanasan global. Pemprov Jatim memberikan dukungan dan fasilitasi yang proporsional atas setiap upaya warga Jatim dalam melakukan pembenahan Jatim secara ekologis. Kedepannya program ini terus dilakukan hingga Batang Sumenep. "Ini bagus sekali untuk dilakukan penanaman mangrove dan pohon cemara laut guna mengatasi abrasi," ujarnya.

H. Ali menyatakan "Kenapa menggunakan mangrove, karena posisi kami di pantai”. Pada waktu itu alasan kenapa memilih mangrove adalah karena posisinya di daerah pepisir pantai, beliau beranggapan cara yang tepat untuk mengatasi masalah lingkungan yang terjadi adalah dengan menggunakan mangrove. Tidak cukup itu saja H. Ali juga memiliki beberapa prinsip yang menunjang keberhasilannya dalam menyelamatkan lingkungan. Prinsip-prinsip konservasi lingkungan menurut $\mathrm{H}$. Ali:

1. Keikhlasan, bagaimana kita harus ikhlas didasari tuntunan agama

2. Menanam dengan hati, menganggap tanaman itu seperti diri kita sendiri

3. Meningkatkan sumberdaya manusia

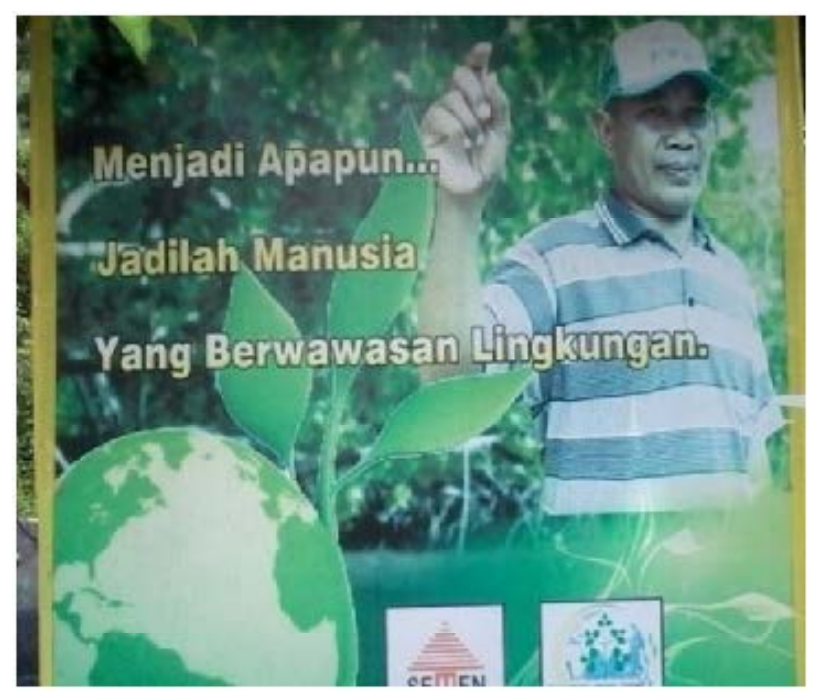

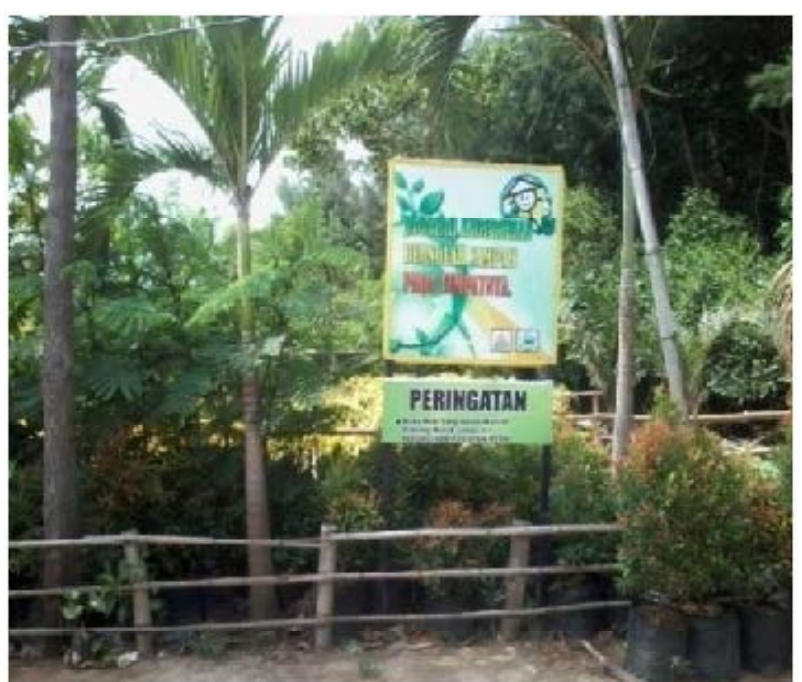

\section{Gambar 2. H. Ali dan kata-kata kritisnya tentang lingkungan}

Dalam keberhasilannya H. Ali tidak lepas dari keinginannya untuk mengubah yang begitu besar, kerja kerasnya, dan pemikiranpemikirannya yang kritis. Pikiran-pikiran kritis H. Ali juga banyak dicurahkan ke dalam tulisantulisan yang dipasangnya di daerah konservasi tersebut seperti yang ada pada gambar di atas.

\section{Proses Objektivasi di Mangrove Center Tuban (MCT)}

Diawali tahun 1972 sampai tahun 1997 yang merupakan kegiatan pribadi H. Ali seorang, selanjutnya guna mengikuti perkembangan akhirnya di tahun 1997 terbentuklah sebuah kelompok tani. Organisasi kelompok tani adalah organisasi yang dikususkan hanya untuk tingkat desa saja. Kelompok tani dibagi dalam dua bagian, yakni kelompok tani Wanabahari untuk yang laki-laki, dan Wanalestari untuk kelompok tani perempuan. Tidak hanya dengan organisasi di tingkat desa, selanjutnya organisasi tingkat Kabupaten Tuban yang didirikan adalah Forum Komunikasi Peduli Lingkungan Pesisir Pantai Tuban (FKPLPT). Forum organisasinya hanya untuk digunakan antar kelompok saja, kalau dengan pemerintah organisasi yang digunakan adalah Kelompok Kerja Mangrove Daerah (KKMD2). 
Tidak sampai di situ, kelembagaan terus mengalami perkembangan hingga sampai regional dengan organisasi yang dibangun adalah ALIPP (Aliansi Independen Peduli Pantura). Selanjutnya, untuk tingkat nasional adalah Yayasan Mangrove Center Tuban (MCT) yang cakupannya lebih luas dibanding dengan organisasi-organisasi yang lainnya tadi. Setiap organisasi diberi ketua sendiri-sendiri. Untuk tingkat desa yang dipilih menjadi ketua adalah orang desa itu, kalau untuk tingkat kabupaten yang diangkat menjadi ketua adalah orang dari kabupaten, pengangkatan ketua tergantung berdasarkan tingkat organisasinya, misalnya ALIPP, ketuanya adalah Totok Nurdianto yang berada di Surabaya.

Ada alasan tertentu, kenapa membuat organisasi-organisasi dalam beberapa bentuk tingkatan organisasi, dengan alasan lawan interaksi yang berbeda-beda, maka dengan adanya beberapa jenis organisasi yang dibuat diharapkan dapat menyesusaikan dengan kebutuhan dalam berhubungan dengan mitra kerja. Misalnya bila akan bermitra dengan pemerintah, kalau pemerintah hubungannya dengan kelompok tani. Kalau bermitra dengan perusahaan pastinya perusahaan tidak mau bermitra dengan kelompok tani, maka forum atau yayasan yang akan diajukan. Kalau mau komunikasi dengan pihak luar daerah maka kelembagaan ALIPP yang akan diajukan, jadi lembaga-lembaga seperti itu dibuat guna untuk menyesuaikan dengan mitra kerja yang bervariatif. Setiap organisasi dulu awalnya ketuanya adalah $\mathrm{H}$. Ali sendiri, tapi setelah berjalan beliau meninggalkannya dan mengangkat ketua baru, sebagai orang yang suka merintis beliau membuat lembaga lagi bila diperlukan, meskipun ditinggal tapi bukan berarti H. Ali melepas lembaga tersebut, beliau tetap menjadi pembina dalam lembaga tersebut.

Meskipun kini H.Ali sudah tidak melakukan pekerjaannya sendiri, namun kendala dalam melakukan terkadang masih saja ada. Dalam menghadapi kendala-kendala yang ada yang penting istiqomah dan bekerja keras tuturnya.
Selama ini di dalam kelembagaan MCT tidak pernah ada konflik sama sekali, hal tersebut terjadi karena prinsip dari seorang $\mathrm{H}$. Ali yang diterapkan di sana. Dengan memegang prinsip bahwa kegagalan adalah keberhasilan yang tertunda, maka setiap kali ada kendala itu dianggap bukanlah apa-apa, karena di sana menganggap bahwa kendala itu adalah ilmu, ilmu untuk perbaikan ke depan. Selanjutnya, bila ada konflik atau perbedaan pendapat, dengan mengaplikasikan tuntunan agama yang diyakininya dalam realitas sehari-hari konflik ditanggapinya dengan senyum. Perbedaan pendapat menurutnya nantinya akan membawa kebaikan, sehingga perbedaan tidak pernah ditanggapinya sebagai sebuah konflik.

Selanjutnya, mengapa tidak pernah ada konflik dikarenakan oleh orang-orang yang diajak melakukan kegiatan tidak dengan rasa untuk kepentingan apapun, menurut pendapat $\mathrm{H}$. Ali sebab timbulnya konflik itu rata-rata dikarenakan pelaku punya tujuan-tujuan tertentu. Menurut H. Ali salah satu faktor kenapa lembaga itu tidak berjalan atau kurang berkembang adalah karena tamu, mengapa begitu? Karena dengan banyaknya tamu yang datang, mau tidak mau tamu-tamu tersebut harus ditemui, sehingga banyak menyita waktu dalam berkerja akibat menemui tamu-tamu tersebut. Dalam menanggapi masalah ini, H. Ali tidak mengizinkan bagi tamu yang berkunjung baik dari mahasiswa, peneliti maupun tamu-tamu lain menemui orang-orang MCT di saat jam kerja. Hal itu dianggap dapat mengganggu jam kerja, sehingga bekerja tidak dapat maksimal. H. Ali mengizinkan kepada siapa pun yang berkepentingan dengan orang-orang di MCT hanya di saat jam istirahat atau di luar jam kerja. Dalam pengorganisasiannya di MCT untuk menerima tamu ada orangnya sendiri, yang biasa menemui tamu dalam kepentingan apapun adalah H. Ali sendiri selaku Pembina tetap di MCT.

Demi keberlanjutan MCT ke depan, salah satu caranya adalah dengan mengadakan kaderisasi. MCT juga bersedia menyekolahkan kader-kadernya yang dianggap mampu untuk 
ikut mengelola kelembagaan MCT tersebut dalam upaya kaderisasi. Saat ini, MCT sudah menyekolahkan dua orang kadernya ke jenjang S2. Dalam masalah sekolah, MCT memiliki pertimbangan-pertimbangan tertentu dalam memilih universitas yang akan dipilihnya untuk menyekolahkan kadernya. Misalnya, saat ini MCT menguliahkan kadernya di Ciputra Surabaya, hal ini diambil oleh MCT berdasarkan pertimbangan bahwa, mahasiswa yang kuliah di Ciputra kebanyakan adalah pengusaha, dengan begitu diharapkan bagi kadernya untuk dapat membangun jaringan ketika kuliah di Ciputra.

Untuk menciptakan organisasi yang bagus dan terarah pengurus ditekankan punya kemandirian yang tinggi, dalam artian pengurus tidak boleh minta-minta. Bagi MCT menerima bantuan yang sifatnya mengikat tidak boleh, serta tidak mencari-cari proyek. Struktur organisasi di MCT terbagi ke dalam dua bagian, yakni bagian pemikir dan bagian pelaksana. Bagian pemikir adalah orang-orang yang dianggap mampu memberikan sumbangan pemikiran bagi perkembangan MCT. Bagian pelaksana adalah orang-orang yang bertugas melaksanakan kegiatan sehari-hari di MCT, misalnya perawatan, pembibitan, dan penanaman, sedangkan peran dari $\mathrm{H}$. Ali sendiri adalah sebagai pembina tetap di Mangrove Center Tuban (MCT).

\section{Proses Internalisasi di Mangrove Center Tuban}

Peran yang dijalankan seorang $\mathrm{H}$. Ali telah berhasil menciptakan sebuah pusat pendidikan lingkungan hidup pesisir dan laut di Kabupaten Tuban Jawa Timur dengan nama Mangrove Center Tuban (MCT). Dalam mengajak masyarakat untuk bergabung awalnya adalah dengan mengkondisikan untuk kepentingan ekonomi. Masyarakat sekitar mau melakukan kegiatan penanaman itu semata-mata karena punya kepentingan ekonomi. Misalnya mereka menanam mangrove untuk makanan ternak, berangkat dari kebutuhan untuk makanan ternak, akhirnya mereka mau menanam mangrove. Selanjutnya, dengan melihat tanaman dan tanah milik $\mathrm{H}$. Ali yang aman ketika sudah ditanami mangrove, lalu warga sekitar bergabung ikut menanam mangrove karena berkeinginan lahannya tersebut juga ikut aman dari kerusakan akibat abrasi. Menurut $\mathrm{H}$. Ali, itu semua adalah perjalanan yang panjang karena dalam menyentuh masyarakat kecil harus melewati kegiatan ekonomi terlebih dahulu, baru masyarakat tergerak bergabung dalam penanaman mangrove, beliau memaparkan:

"Saya ini punya teori bagaimana
mau mengajak orang, sebelum kami
mengajak, terlebih dahulu melihat
latar belakang orang tersebut, terus
kepentingannya apa, jadi setelah tau
latar belakang, kita tau kepentingannya
bagaimana, maka kepentingan mereka
bisa terwujud dengan kegiatan
konservasi tadi. Itu teori kami dalam
mengajak untuk kegiatan menanam,
kegiatan lingkungan, dan kegiatan
konservasi”. (hasil wawancara 20 April
2015)

Pendekatan yang digunakan oleh $\mathrm{H}$. Ali dalam mengajak orang yaitu sebelum beliau mengajak, dilihat dulu bagaimana latar belakang orang yang akan diajaknya tersebut, serta melihat kepentingan apa dari orang tersebut. Jadi, setelah mengetahui latar belakang dan bagaimana kepentingan mereka, maka dapat terwujud melalui kegiatan korservasi baru. Begitulah pendekatan yang digunakan oleh $\mathrm{H}$. Ali dalam mengajak untuk kegiatan menanam, pelestarian lingkungan maupun konservasi alam, jadi dimulai terlebih dahulu dengan melihat bagaimana latar belakang dan kepentingannya.

Dengan visi terciptanya kelestarian lingkungan pesisir pantai Tuban yang bersih, indah, dan asri guna mewujudkan kesejahteraan masyarakat. Hal yang dilakukan MCT dalam mewujudkan kesejahteraan masyarakat adalah melalui pemberdayaan. Salah satu bentuk 
pemberdayaan masyarakat yang sudah dilakukan MCT antara lain adalah dengan membuka lapangan kerja baru kepada warga sekitar.

Selain memberi pekerjaan, MCT juga memberikan fasilitas kepada warga bagi yang menginginkan membuka usaha sendiri, yakni memberikan tempat di lokasi MCT untuk membuka warung-warung jualan yang dapat digunakan mencukupi kebutuhan pengunjung yang datang. Bagi warga yang berjualan hanya diprioritaskan kepada warga Jenu saja, mengingat masih banyak warga Jenu yang membutuhkan pekerjaan. Untuk berjualan di MCT warga tidak perlu membayar tempat atau tidak dipungut biaya apapun, hanya diwajibkan untuk ikut menjaga lingkungan agar tetap bersih. Apabila pedagang buka sampai malam, MCT hanya minta pedagang untuk ganti uang listrik saja.

Berdasarkan pernyataan para pedagang di MCT, hasil dari berjualan tersebut cukup memberikan pemasukan yang lumayan. Upaya yang dilakukan oleh $\mathrm{H}$. Ali dalam bentuk pemberdayaannya dapat dikatakan berhasil, terlebih lagi kalau di saat pengunjung ramai. MCT saat ini memang sudah banyak didatangi oleh pengunjung, bahkan sudah ada yang berlangganan setiap tahun mengadakan acara diklat. Pengunjung senang mengadakan acara di MCT karena merasa aman, lokasinya dekat dengan kampung, serta biaya yang dapat dikatakan murah dengan fasilitas yang cukup memadai.

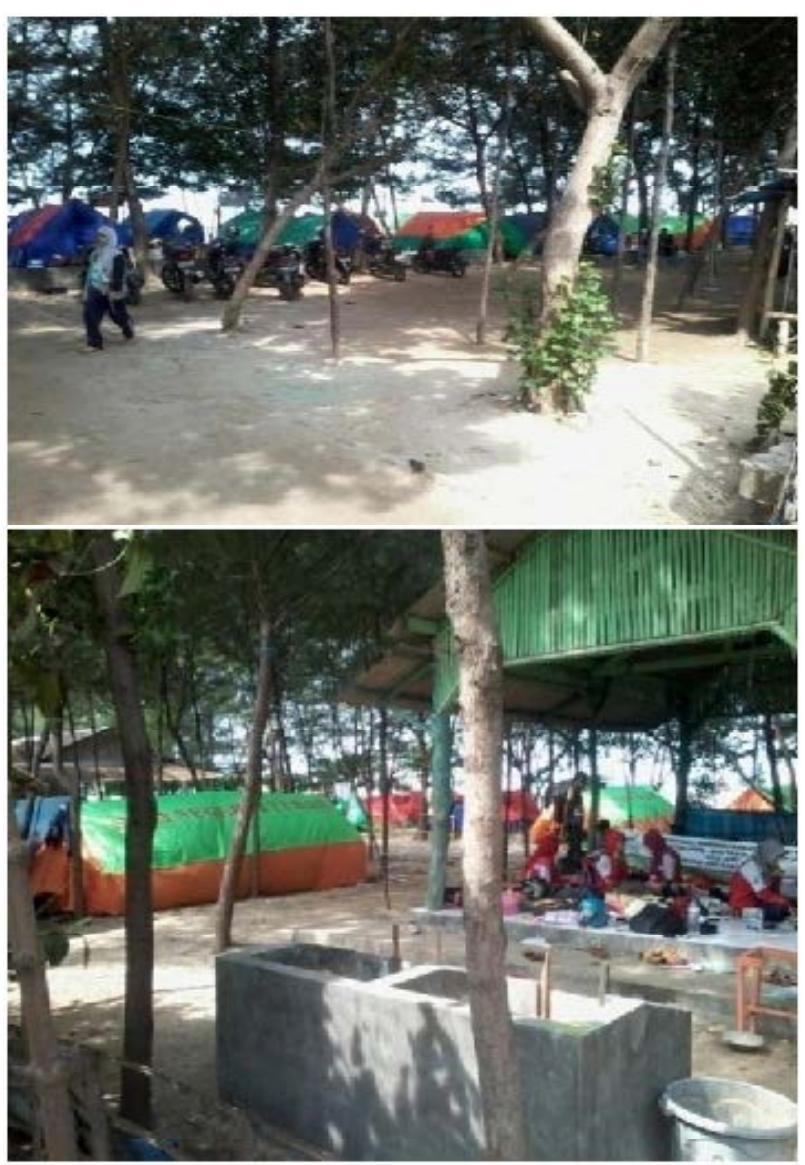

Gambar 3. Pengunjung berkemah di MCT

MCT juga membuka diri untuk tempat pelatihan budidaya mangrove dan cemara laut. Tergerak membuat pelatihan dan menjadi lembaga yang paling aktif malakukan kegiatan lingkungan, kini lembaga tersebut sudah banyak dikenal di berbagai tempat. MCT terus merangkai mimpi-mimpinya untuk menjadikan dirinya sebagai tempat belajar lingkungan dan kehutanan, serta pemberdayaan ekonomi masyarakat. Sebagai upaya pemberdayaan MCT berusaha untuk menularkan ilmu kepada masyarakat, di mana pun itu yang penting masyarakat itu berdaya. MCT juga memiliki relawan yang bekerja tidak mendapatkan apa-apa, ada yang semi (mendapatkan upah sedikit), dan ada yang memang murni pekerja. H. Ali mengatakan bahwa hidup kita harus mengabdi dan berguna bagi orang lain, di samping itu lingkungan dan ekonomi harus berjalan bersama menurut pendapatnya. 


\section{PEMBAHASAN}

Kenyataan hidup sehari-hari yang bersifat intersubjektif, dipahami oleh seorang H. Ali yang hidup di daerah pesisir sebagai bentuk kepatuhan. Sekitar tahun 1970, pantai yang berbatasan dengan desa mulai terkikis habis oleh abrasi. Sampai akhirnya pada tahun1974-an rob besar menghantam desanya. Jarak rumah yang tadinya sekitar 300-an meter ke pantai hanya tiggal beberapa meter saja. Kejadian itu menggugah $\mathrm{H}$. Ali menapaktilasi jejak banjir dengan menanami mangrove. H. Ali pada saat itu adalah seorang warga biasa yang sedang mengakses pendidikan di pondok pesantren Manbail Futuh. Kendati pun kenyataan hidup sehari-hari merupakan dunia intersubjektif, namun bukan berarti antara orang yang satu dengan orang yang lain selalu memiliki kesamaan perspektif dalam memandang dunia bersama. "Banyak yang menyebut $\mathrm{H}$. Ali gila, tak ada kerjaan, dan membuang-buang tenaga" waktu itu.

Setiap orang memiliki perspektif berbedabeda dalam memandang dunia yang bersifat intersubjektif. Perspektif orang yang satu dengan yang lain tidak hanya berbeda, tetapi sangat mungkin juga bertentangan. Namun, dengan melihat menanam mangrove ternyata ada hasilnya hingga akhirnya masyarakat turut menanam mangrove, maka timbullah kesadaran bersama. Kini ada persesuaian yang berlangsung terus-menerus antara makna-makna dari $\mathrm{H}$. Ali dengan orang-orang di sekitarnya. Sekarang, kesadaran bersama mengenai kenyataan di dalamnya menuju sikap alamiah atau sikap kesadaran akal sehat sudah terbangun. Sikap melakukan penanaman telah mengacu kepada suatu dunia yang sama-sama dialami banyak orang. Menurut Berger, jika ini sudah terjadi maka dapat disebut dengan pengetahuan akal sehat (common-sense knowledge), yakni pengetahuan yang dimiliki semua orang dalam kegiatan rutin yang normal dan sudah jelas dengan sendirinya dalam kehidupan sehari-hari.

Kenyataan hidup sehari-hari, yang diterima sebagai kenyataan oleh masyarakat merupakan faktisitas yang memaksa dan sudah jelas dengan sendirinya, serta akan berlangsung terus-menerus. Namun, masyarakat dapat saja menyangsikan atau mengubahnya. Untuk mengubah kenyataan, perlu peralihan yang sangat besar, kerja keras, dan pikiran kritis. Seperti yang telah dilakukan oleh seorang H. Ali yang berusaha mengubah kenyataan hidup sehari-hari yang dialaminya. Kenyataan waktu itu pesisir pantai Jenu terkena libasan ombak yang begitu dahsyat hingga terjadilah kerusakan tanah yang luar biasa. Daya terjang ombak sampai ke daratan dan merusak infrastruktur di pinggir-pinggir jalan raya. H. Ali tidak menerimanya begitu saja, tetapi berusaha untuk menggubahnya dengan usaha dan tekadnya. Berawal dari 1,2 hektar tanah di tepi pantai yang ia miliki, H. Ali berusaha menanami kembali tanahnya dengan beberapa pohon mangrove, hingga terjadilah peralihan. Dengan bekerja keras H. Ali memungut bibit mangrove dari desa ke desa lain, bahkan rela ambil bibit jauh-jauh dari Ujung Pangkah Kulon Gresik dan Brondong Lamongan hanya dengan menggunakan sepeda ontel.

Apa yang dilakukan tidak dari sekedar kerja keras saja, melainkan dengan dukungan pemikiran-pemikirannya yang kritis. Pemikiranpemikiran kritis dari H. Ali dipaparkannya melalui prinsip-prinsipnya dalam melakukan konservasi. Prinsip-prinsip konservasi lingkungan tersebut antara lain (1) keikhlasan, bagaimana kita harus ikhlas didasari tuntunan agama, (2) menanam dengan hati, menganggap tanaman itu seperti diri kita sendiri, dan (3) meningkatkan sumber daya manusia. Selain itu, pemikirannya yang kritis juga banyak dipaparkannya dalam sebuah tulisan yang dipajang di kawasan konservasi tersebut seperti "jadi apaapun...jadilah manusia yang berwawasan lingkungan".

Bagi H. Ali makna menanam mangrove adalah untuk keselamatan lingkungan, dengan harapan tanahnya selamat serta bernilai ibadah, sedangkan bagi orang lain, menanam mangrove adalah untuk pakan ternak. Pada gilirannya, 
interaksi itu kembali melahirkan tipifikasi baru, yakni dengan melakukan penanaman ternyata ada hasilnya. H. Ali berusaha mencurahkan diri dengan menanami kembali tanahnya dengan beberapa pohon mangrove, penanaman dilakukakannya terus-menerus sebagai aktivitas sehari-hari. Di balik pembiasaan ini, juga sangat mungkin terjadi inovasi, akhirnya di tahun 1997 terbentuklah sebuah kelompok tani.

Bagi H. Ali kegiatan konservasi yang telah dilakukannya adalah wujud dari pelaksanaan nilai-nilai keagamaan dan kepedulian terhadap lingkungan. Hal ini tidak terlepas dari inspirasi ayat-ayat Al-Qur'an yang menjelaskan tentang tasbih mahkluk di langit dan di bumi, seperti yang dijelaskan dalam QS Al-Isra (17): 44, "Langit yang ketujuh, bumi dan semua yang ada di dalamnya bertasbih kepada Allah. Dan tidak ada sesuatu pun melainkan bertasbih memuji-Nya, tetapi kamu sekalian tidak mengerti tasbih mereka. Sesungguhnya Dia adalah Maha Penyantun lagi Maha Pengampun". Didukung adanya dorongan agama dan keyakinannya, apa yang dilakukannya dianggapnya sebagai Ibadah, untuk sedekah melalui bibit. Tidak cukup itu saja, H. Ali juga memiliki beberapa prinsip yang mendukung terbentuknya konstruksi, prinsipprinsip tersebut adalah keikhlasan, bagaimana kita harus ikhlas dengan didasari tuntunan agama, menanam dengan hati, menganggap tanaman itu seperti diri kita sendiri, dan meningkatkan sumber daya manusia.

Kelompok tani dibagi dalam dua bagian, yakni kelompok tani Wanabahari untuk yang laki-laki, dan Wanalestari untuk kelompok tani perempuan. Setelah kelompok tani muncullah inovasi baru yakni organisasi tingkat Kabupaten Tuban yang didirikan adalah Forum Komunikasi Peduli Lingkungan Pesisir Pantai Tuban (FKPLPT), Kelompok Kerja Mangrove Daerah (KKMD2), ALIPP (Aliansi Independen Peduli Pantura), hingga terbentuklah Yayasan Mangrove Center Tuban (MCT). Bagi MCT kebiasaan menanam itu adalah konservasi. Setiap lembaga memiliki peran dan identitas masing-masing.
Untuk tingkat desa (kelompok tani) yang dipilih menjadi ketua adalah orang desa itu, kalau untuk tingkat kabupaten (FKPLPT) yang diangkat menjadi ketua adalah orang dari kabupaten, pengangkatan ketua tergantung berdasarkan tingkat organisasinya, misalnya ALIPP, ketuanya adalah Totok Nurdianto yang berada di Surabaya.

Ada alasan tertentu, kenapa membuat organisasi-organisasi dalam beberapa bentuk tingkatan organisasi, alasannya adalah lawan interaksi yang berbeda-beda. Dengan adanya beberapa jenis organisasi yang dibuat diharapkan dapat menyesusaikan dengan kebutuhan dalam berhubungan dengan mitra kerja. Misalnya, bila akan bermitra dengan pemerintah, kalau pemerintah hubungannya dengan kelompok tani. Kalau bermitra dengan perusahaan pastinya perusahaan tidak mau bermitra dengan kelompok tani, maka forum atau yayasan yang akan diajukan. Kalau mau komunikasi dengan pihak luar daerah, maka kelembagaan ALIPP yang akan diajukan, jadi lembaga-lembaga seperti itu dibuat untuk menyesuaikan dengan mitra kerja yang bervariatif. Setiap organisasi dulu awalnya ketuanya adalah $\mathrm{H}$. Ali sendiri. Akan tetapi, setelah berjalan beliau meninggalkannya dan mengangkat ketua baru, sebagai orang yang suka merintis beliau membuat lembaga lagi bila diperlukan. Meskipun ditinggal, tapi bukan berarti H. Ali melepas lembaga tersebut, beliau tetap menjadi pembina dalam lembaga tersebut.

Melalui peran agen proses objektivasi Mangrove Center Tuban (MCT) terbentuk, ada beberapa peranan agen yang memainkan peranannya sebagai pemimpin dan membentuk kesadaran individu atau sekelompok individu. Mulai dari membuka kesadaran, melakukan proses pelembagaan, dan habitualisasi. Agen dalam masyarakat, terutama $\mathrm{H}$. Ali merupakan aktor yang paling utama dalam pembentukan kesadaran masyarakat di Mangrove Center Tuban(MCT).

MCT telah menjadikan kawasan tersebut menjadi sebuah objek wisata pantai, yang ternyata banyak diminati oleh wisatawan. Hal 
ini tidak lepas dari berbagai sosialisasi yang sudah dilakukan oleh H. Ali. Dalam mengajak masyarakat untuk bergabung, awalnya adalah dengan mengkondisikan untuk kepentingan ekonomi. Masyarakat sekitar mau melakukan kegiatan penanaman itu semata-mata karena punya kepentingan ekonomi. Misalnya mereka menanam mangrove untuk makanan ternak, berangkat dari kebutuhan untuk makanan ternak, akhirnya mereka mau menanam mangrove. Pendekatan yang digunakan oleh $\mathrm{H}$. Ali dalam mengajak orang dengan melihat dulu bagaimana latar belakang orang yang akan diajaknya dan melihat kepentingan apa dari orang tersebut. Setelah mengetahui latar belakang dan bagaimana kepentingan mereka, maka sosialisasi dapat terwujud melalui kegiatan korservasi.

MCT juga membuka diri untuk tempat pelatihan budidaya mangrove dan cemara laut. Tergerak membuat pelatihan dan menjadi lembaga yang paling aktif malakukan kegiatan lingkungan, kini lembaga tersebut sudah banyak dikenal di berbagai tempat. MCT terus merangkai mimpi-mimpinya untuk menjadikan dirinya sebagai tempat belajar lingkungan dan kehutanan, serta pemberdayaan ekonomi masyarakat. Sebagai upaya pemberdayaan MCT berusaha untuk menularkan ilmu kepada masyarakat, di mana pun itu yang penting masyarakat itu berdaya. MCT juga memiliki relawan yang bekerja tidak mendapatkan apa-apa, ada yang semi (mendapatkan upah sedikit), dan ada yang memang murni pekerja. H. Ali mengatakan bahwa hidup kita harus mengabdi dan berguna bagi orang lain. Di samping itu, lingkungan dan ekonomi harus berjalan bersamaan menurut pendapatnya.

Salah satu bentuk pemberdayaan masyarakat yang sudah dilakukan MCT antara lain adalah dengan membuka lapangan kerja baru kepada warga sekitar. Selain memberi pekerjaan, MCT juga memberikan fasilitas kepada warga yang menginginkan untuk membuka usaha sendiri, yakni memberikan tempat di lokasi MCT untuk membuka warung jualan untuk mencukupi kebutuhan pengunjung yang datang. Bagi warga yang berjualan hanya diprioritaskan kepada warga Jenu saja, mengingat masih banyak warga Jenu yang membutuhkan pekerjaan. Untuk berjualan di MCT, warga tidak perlu membayar tempat atau tidak dipungut biaya apapun, hanya diwajibkan untuk ikut menjaga lingkungan agar tetap bersih, dan bila pedagang buka sampai malam MCT hanya minta pedagang untuk mengganti uang listrik saja.

$\mathrm{H}$. Ali adalah seorang guru dengan gelar $\mathrm{S}$. Ag, sekalipun yang dipelajari adalah Pendidikan Islam, tetapi beliau mengajar ekologi dan biologi di MTSn Manbaul Futuh, jadi apa yang diajarkan H. Ali adalah keterkaitan Islam dan tumbuh-tumbuhan. Selain itu, H. Ali adalah Pembina tetap di MCT yang sudah dirintisnya sejak dari dulu. H. Ali adalah orang yang paling memberikan pengaruh dalam proses konstruksi sosial konservasi lingkungan di Mangrove Center Tuban (MCT).

\section{KESIMPULAN}

Konstruksi sosial konservasi lingkungan di Mangrove Center Tuban berawal dari kegiatan penanaman mangrove yang dilakukan sehari-hari. Kegiatan konservasi dilakukan sebagai wujud pelaksanaan nila-nilai keagamaan, kepedulian terhadap lingkungan tidak lepas dari inspirasi ayat Al-Qur'an (QS Al Isra (17): 44). Apa yang dilakukannya dianggap sebagai ibadah, yakni untuk sedekah melalui bibit. Selain itu, dengan prinsip-prinsip seperti keikhlasan, bagaimana kita harus ikhlas didasari tuntunan agama, menanam dengan hati, menganggap tanaman itu seperti diri kita sendiri, dan meningkatkan sumber daya manusia.

Kegiatan penanaman pada akhirnya menjadi sebuah kebiasaan, sehingga terjadilah pelembagaan. Lembaga pertama yang terbentuk adalah kelompok tani, hingga terjadi inovasi baru organisasi tingkat Kabupaten Tuban yang didirikan adalah Forum Komunikasi Peduli Lingkungan Pesisir Pantai Tuban (FKPLPT), 
Kelompok Kerja Mangrove Daerah (KKMD2), ALIPP (Aliansi Independen Peduli Pantura), hingga terbentuklah Yayasan Mangrove Center Tuban (MCT). Setiap lembaga memiliki peran dan identitas masing-masing. Melalui peran agen proses objektivasi Mangrove Center Tuban (MCT) terbentuk. Ada beberapa peranan agen yang memainkan peranannya sebagai pemimpin dan membentuk kesadaran individu atau sekelompok individu. Membuka kesadaran, melakukan proses pelembagaan dan habitualisasi. Agen tersebut adalah seorang $\mathrm{H}$. Ali yang merupakan aktor paling utama dalam pembentukan kesadaran masyarakat di Mangrove Center Tuban (MCT).

Berbagai sosialisasi dilakukan, dalam mengajak untuk kegiatan konservasi dimulai terlebih dahulu dengan melihat bagaimana latar belakang dan kepentingannya. Misalnya, menanam mangrove untuk makanan ternak, menanam mangrove karena membutuhkan pekerjaan, dan menanam mangrove karena berdagang di wilayah konservasi. Semua itu, yang melatar belakangi masyarakat melakukan konservasi. Kini MCT telah menjadi kawasan objek wisata pantai, yang ternyata banyak diminati oleh wisatawan. MCT juga membuka diri untuk tempat pelatihan budidaya mangrove dan cemara laut. Tergerak membuat pelatihan dan menjadi lembaga yang paling aktif malakukan kegiatan lingkungan, kini lembaga tersebut sudah banyak dikenal di berbagai tempat. MCT terus merangkai mimpi-mimpinya untuk menjadikan dirinya sebagai tempat belajar lingkungan dan kehutanan, serta pemberdayaan ekonomi masyarakat.

\section{DAFTAR PUSTAKA}

Adisasmita, R. (2006). Pembangunan Kelautan dan Kewilayahan. Yogyakarta: Graha Ilmu. Amelia. (2013). Konservasi Wilayah Pesisir. Retrieved from http://uwityangyoyo. wordpress.com/2013/05/19/konservasiwilayah-pesisir/

Berger, Peter L \& Luckman, T. (2012). Tafsir Sosial Atas Kenyataan Risalah tentang Sosologi Pengetahuan. Jakarta: LP3ES.

Novianti, D. (2013). Peduli Lingkuan Pesisir Jawa. Retrieved from http://repository.upi. edu/2976/6/S_PSI_0901520_Chapter3.pdf Parlan, H. (2002). Reposisi Gerakan Lingkungan Menuju Gerakan Sosial. Ilmu Sosial Transformatif, 12(3). 